\title{
機能性発声障害の診断における問診および自覚度評価のポイント
}

\author{
田口＼cjkstart亜紀
}

\begin{abstract}
要 約：機能性発声障害はしばしば精神身体的問題や音声酷使の結果として生じる。このた め, 症状の発症状況や心因的背景を詳細に聴取することが診断にとって重要である。音声障害 の自覚度を的確に評価するために，われわれはVoice Handicap Index を用いた。これは音声 障害により患者自身が感じているハンディキャップの程度を，自己記入式問診票により評価す るものである。その結果, 機能性発声障害では 40 歳代あるいは過緊張性発声障害患者の VHI スコアが高かった。 また，他疾患に比べ感情的側面のスコアは機能的あるいは身体的側面スコ アより高かった.VHI は病因的背景を評価するうえで有用であった。今回の結果より，機能性 発声障害が疑われる患者においては，会話時の努力感や発声障害による社会生活上の制限など に関する問診が重要であると考えられる。
\end{abstract}

索引用語：機能性発声障害, 問診, Voice Handicap Index, 日本語版, 自覚度評価

\section{Usefulness of Examination by Interview and Subjective Assessment of Symptoms for Diagnosis of Functional Dysphonia}

\begin{abstract}
Aki Taguchi
Abstract: Functional voice disorders often develop from a psychophysiological disorder or as a consequence of vocal misuse. Therefore, interviewing the subject about the situation surrounding the onset of symptoms and his psychological background is an important step for diagnosis. To achieve sufficient subjective assessment of voice disorders, we introduced the Voice Handicap Index (VHI), a self-administered questionnaire that quantifies the degree of a patient's handicap related to his voice disorder. Patients in the 40-49 age bracket and cases of hyperfunctional dysphonia showed relatively high VHI scores. Also, compared to other disorders, emotional scores were higher than functional or physiological scores. VHI was effective for evaluating etiological background. The present study indicated that examination by interview in suspected cases of functional voice disorder should be focused on sense of effort when talking and restrictions on social life caused by the vocal disturbance.
\end{abstract}

Key words: functional dysphonia, examination by interview, Voice Handicap Index, Japanese version, subjective assessment 


\section{はじめに}

機能性発声障害の診断においては内視鏡による喉頭 所見の観察はもちろん重要であるが, 発声障害の原因, 状況，程度を把握するために問診がキーポイントとな る.そして，その結果に基づいて，患者が自分の心理 状態や発声状態を正しく認識し，自らの意志と努力に よって，より良い音声を再獲得できるように誘導する ことが重要である。

機能性発声障害の分類法にはいくつかあるが，病因 論的には精神神経的なものと声の濫用などにより二次 的に生じるものとに分けられる ${ }^{11}$.しかし, 両者は明確 に区別できないことも多く，問診にあたってはこのこ とも念頭においておかねばならない。これらのことを 踏まえ，機能性発声障害の問診のポイントについて提 示する.

また，われわれは音声の自覚的な評価法の一つとし て，近年アメリカでしばしば用いられているVoice Handicap Index (VHI $)^{2)}$ に注目し，これを機能性発声 障害例に用い, 特徵的所見, 他疾患との比較, 病態の 違いによる検討を行った。このVHIの結果を通して 機能性発声障害の問診のポイントについても述べる。

\section{問診}

まず機能性発声障害の特徵的症状について挙げる. 香田ら ${ }^{3)}$ は, (1)話していると息苦しくなる，(2)話すと疲 れを感じる, (3)話していると声が途切れる, (4)話して いると声が裏返る，(5)高い声が出しにくい，66きな 声が出しにくい，(7)声が全く出ない，などの症状が多 く見られたと述べている。このような患者の訴えがあ る場合には，機能性発声障害を疑ってその誘因や背景 に関する問診を行う必要がある。

具体的には，まず発症の機転や心因的背景を聞き出 す。機能性発声障害症例では心因的要因を有する例が 多いため，ぞのような状況で発声障害が生じるかを明 確に把握することが重要である，発症状況から心因的 背景を理解できることもある. 次に, 発声障害発症前 に誘因となるきっかけはなかったかを問う。当科で経 験した症例では失恋, 学校・職場でのいじめ, 勉強や 親の介護等による精神的ストレス，ひきこもりなどが あった。また声の濫用歷を聴取することも重要である。 感冒時に声を濫用した後, 感冒が軽快しても発声障害 が残った例も見受けられる。

次に，発声障害が出現する状況を聴取することであ る. 人前に出ると大きな声が出なくなったり, 職場・
学校に行くと発声障害が増悪したり, いじめやストレ スを感じると声が出なくなったりする場合がある．精 神科疾患の有無・投薬歴の有無も確認しておく．特に 心因性発声障害の患者などで精神科疾患の関与の可能 性がある場合には，精神科や心療内科などとの連携が 必要である。

\section{Voice Handicap Index（VHI）による自覚度評価}

VHI は 1997 年 Jacobson ら ${ }^{2}$ が提唱した音声障害 に対するアンケート方式の評価方法で，心理社会的に 患者が自分の音声障害をどのようにとらえているかを 機能的，身体的および感情的側面から評価するもので ある. VHI は機能的側面 $(F)$, 身体的側面 $(\mathrm{P})$, 感情的 側面(E)の 3 つの subscale より構成されており，それ ぞれ 10 項目ずつの質問項目がありランダムに配置さ れている。われわれはこれを日本語に訳した (表 1$)^{4)}$. 機能的側面は発声障害による社会生活での支障度や社 会活動での制限を問う内容，身体的側面は声の状態が どの程度悪いと感じているか，それに対する自分の努 力の度合いを問う内容, 感情的側面は声に対する不安 や精神的な抑圧などを問う内容となっている.VHI は これらの項目ごとに 0 ～点の 5 段階で回答するアン ケート形式になっており，点数が高いほど声に対する ハンディキャップを強く感じていることになる.

今回，対象として検討したのは 2002 年 9 月〜2006 年 9 月の間に当科音声外来を受診し，機能性発声障害 と診断された 26 例である。性別は男性 6 例，女性 20 例，年齢は 15〜80 歳で平均年齢は 42.1 歳であった。 検討項目は年齢および男女別の VHI スコア，他疾患 とのVHI スコアの比較, 過緊張性発声障害と低緊張 性発声障害での VHI スコアの比較とした。

機能性発声障害症例全体のVHI スコアの平均は 50.7 であった。年齢別では 40 歳代においてスコアが 61.0 と高値を示したが(図 1)，10，20 歳代の若年者も 比較的高いスコアを示した. 男女別では男性が 54.2 , 女性が 50.5 と男性のほうがややスコアは高かったが 統計学的な有意差はなかった (図 2). 次に声帯結節や 声帯ポリープなどの腫瘤性病変 (56 例), 喉頭肉芽腫 (11 例)，片側性声帯麻痺症例 (49 例) との比較を行っ た。その結果, 機能性発声障害例の VHI は声帯麻痺例 とともに，他疾患より高かった（図 3)。これはRosen ら5)の報告と同様の結果であった。また機能性発声障 害症例で特徵的であったのは，他疾患に比べて感情的 側面のスコアが高かったことである．他疾患と比べて スコアが高かった項目は, 『私は一生懸命声を出さない 
表 1 Voice Handicap Index 日本語版

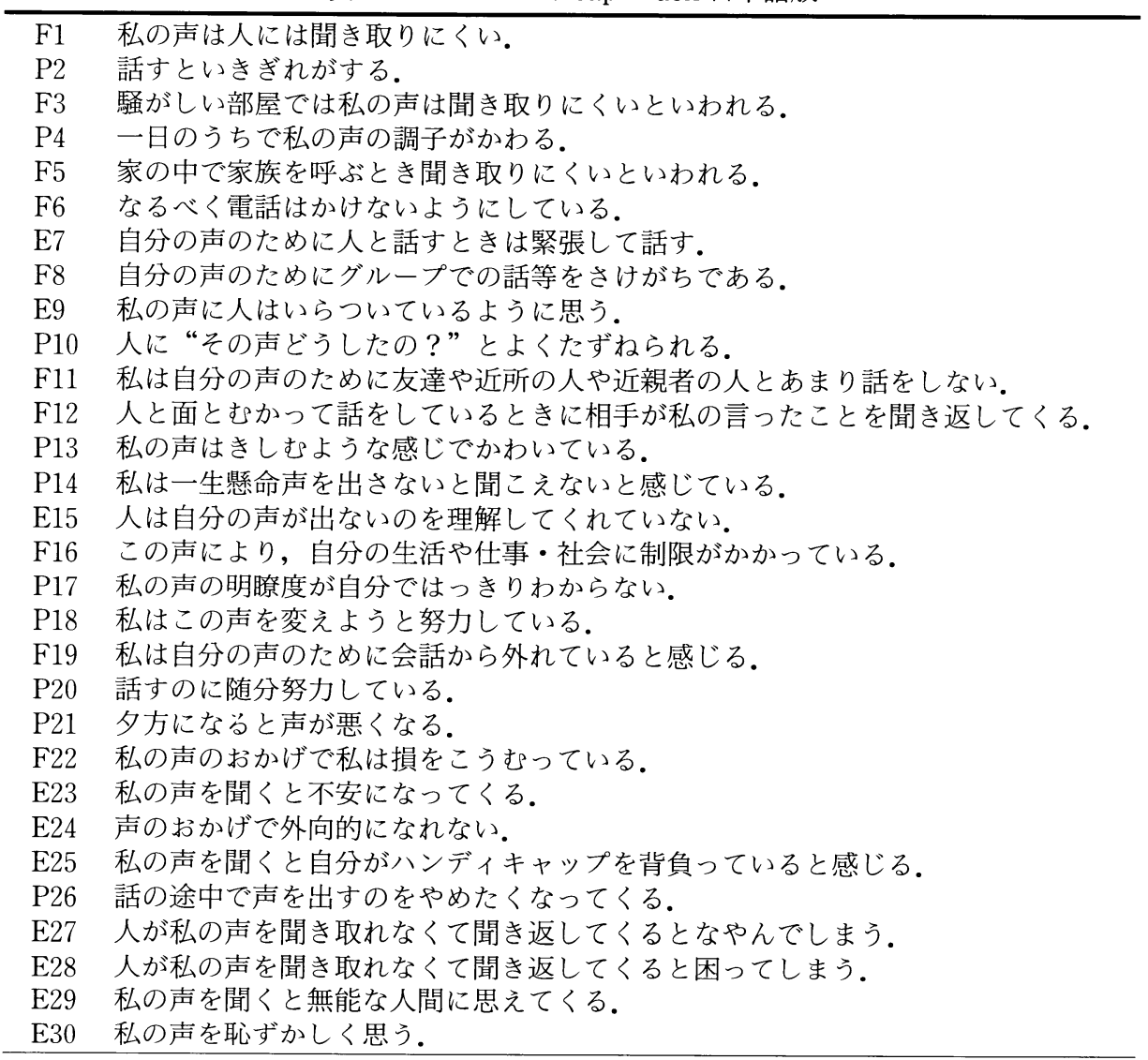

$\mathrm{P}$; 身体的側面, $\mathrm{F}$; 機能的側面, $\mathrm{E}$ : 感情的側面

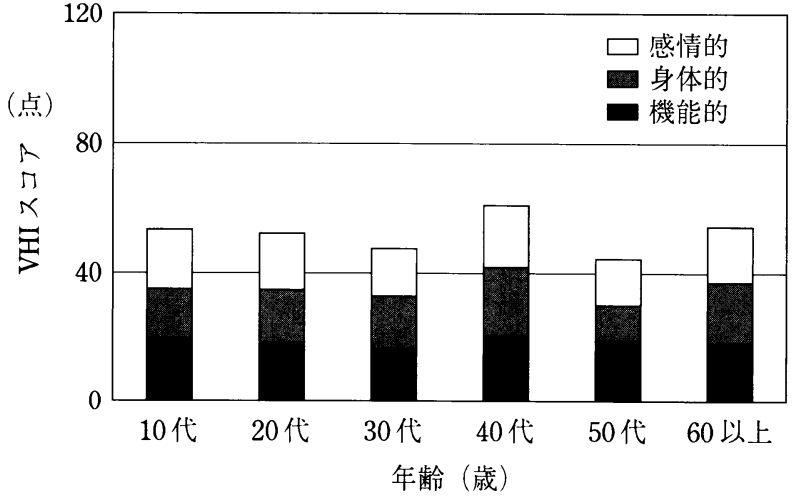

図 1 機能性発声障害における年齢別の VHI スコア

と聞こえないと感じている』，『声を変えようと努力し ている』などの声に対する努力感に関する項目であっ た.また『自分の声のために緊張して話す』という項 目も高いスコアを示した。

次に機能性発声障害症例を, 低緊張性症例 (14 例) と過緊張性症例（9 例）に分類してVHI スコアを検討 すると, 過緊張性が 60.3, 低緊張性が 45.9 と過緊張性 のほうが高いスコアを示した（図 4). 側面別でもいず れの側面においても過緊張性のほうがスコアは高く， 特に感情的側面でその差が大きかった。すなわち，過

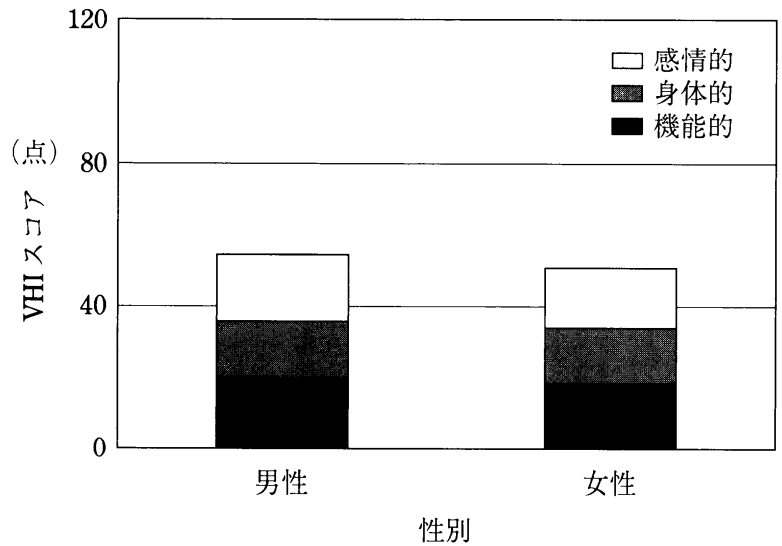

図 2 機能性発声障害における性別の VHI スコア

緊張性症例のほうが声に対する不安や抑圧を感じてい るという結果であった。さらに詳細に検討すると，共 通してVHI スコアが高かったのは，『私の声は聞き取 りにくい』，『人によく尋ねられる』という他人が自分 の声を変えないと聞き取りにくいと感じている項目で あった。また，低緊張性に比べて過緊張性の症例で VHI スコアが高い傾向であった項目は，『声により自 分の生活や仕事, 社会に制限がかかっていること』,『人 と話すときに緊張感を感じる』, 『自分の声に対して不 


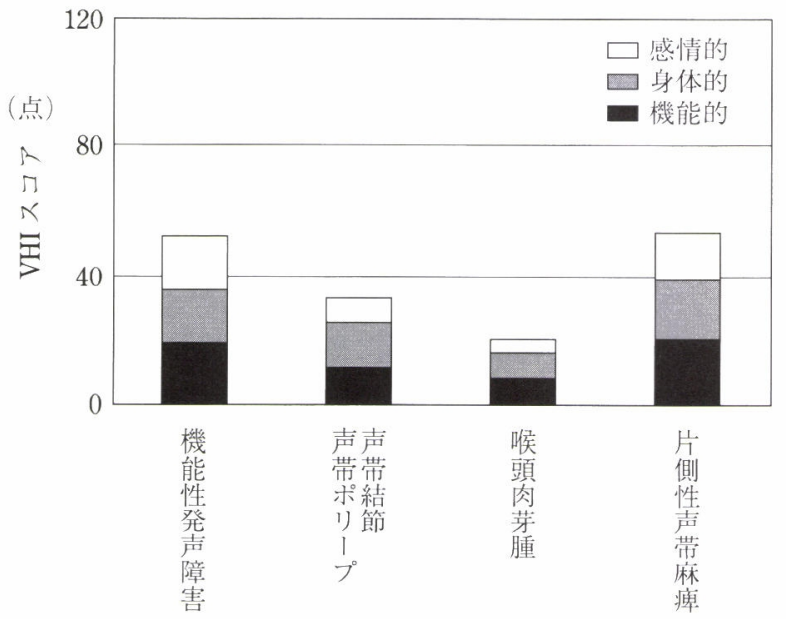

図 3 疾患別の VHI スコア

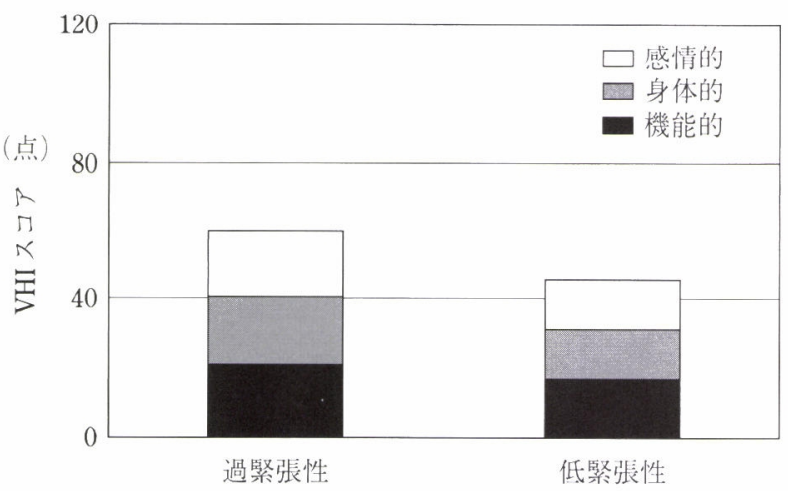

図 4 機能性発声障害における病態別のVHI スコア

安を感じている』という不安や緊張感を感じるといっ た項目であった。

\section{症例}

症例 $1 ： 61$ 歳男性, 過緊張性発声障害症例

主訴：発声困難，嗄声

現病歴：2006 年 5 月 24 日, 脳幹梗塞を発症。発症 後, 構音訓練をリハビリテーション病院で行った。構 音障害は改善したものの, 6 月下旬より嗄声, 発声時の 喉のつまり感を自覚していた。症状が軽快しないため 同年 8 月，当科外来を受診した。

現症および経過：喉頭所見では発声時の披裂一喉頭 蓋間の短縮, 声带・仮声带・披裂部の過内転を認めた (図 5). 初診時のVHI スコアは機能的側面が 30 , 身体 的側面が 18 , 感情的側面が 28 であった。構音訓練を契 機として発症した過緊張性発声障害と診断し, 音声治 療在開始した。治療当初, 過緊張発声のために喉頭肉 芽腫が見られたが，リラクゼーション法を中心とした 音声治療を施行した結果, 喉頭肉芽腫は消失し, 過緊

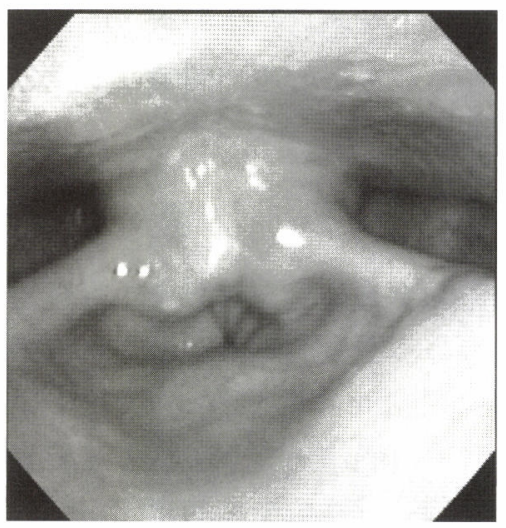

図 5 過緊張発声障害症例の発声時 喉頭所見 (症例 1)。発声時に声 带, 仮声带の過内転が認められ た.

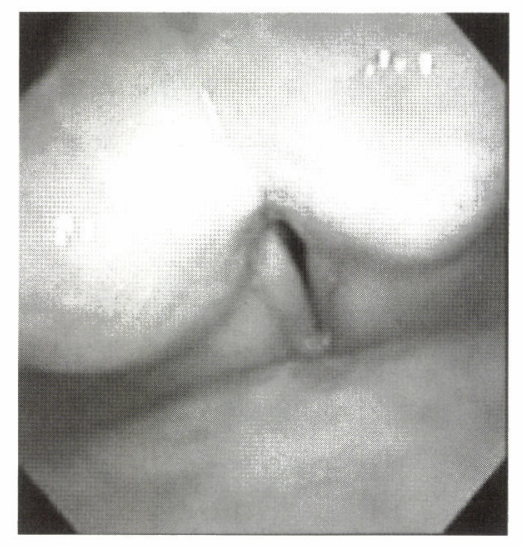

図 6 低緊張発声障害症例の発声時 喉頭所見 (症例 2). 発声時に声 門後部の間陌が認められた。

張発声も音声治療開始後 6 カ月で軽快した。 症例 2:32 歳女性, 低緊張性発声障害症例 主訴：声の途切れ

現病歴：1998 年頃より,ときおり声の途切れを自覚 していた。 2004 年 12 月下旬より会話時に症状が増強 するようになり，その後も増悪傾向があった．特に職 場の特定の人との会話時に声が出なくなることがあっ た。このため，2005 年 1 月に当科受診した。

現症および経過：喉頭所見では発声時に軽度の声門 間隙を認め, 声の途切れ, 音量の減少を認めたが, 音 声振戦や痓變性発声障害の所見はなかった (図 6). 受 診時のVHI スコアは機能的側面が 7, 身体的側面が 9 , 感情的側面が 3 であり，スコアは比較的低值であ った。職場での人間関係やストレスが誘因となった低 緊張性発声障害と診断し, 音声治療を開始した。経過 中，職場での人間関係のトラブル等を考えると発声が 
苦しいと感じ，泣き出したくなるようなこともあった が治療開始から 3 力月で声門間隙は消失し, 自覚症状 も軽快した。

\section{考察}

機能性発声障害とは, 発声器官に器質的変化を認め ないにもかかわらず音声障害を呈する状態と定義され ている ${ }^{6}$. 機能性発声障害症例のなかで，いわゆる心因 性失声症・音声衰弱症・ピッチ障害・仮声帯発声など は明らかな心因の存在や情緒的素因が認められること が多いといわれている77. 特に心因性失声症における 診断の根拠としては, 音声症状と局所所見の不一致が あるとされている8 .また，機能性発声障害の治療に対 しては，音声治療と心身医学的治療が有効とされてお $\eta^{7)}$, 城本 ${ }^{9)}$ も機能性発声障害症例に対して音声治療 とカウンセリングが有効であったと報告している。こ のように，患者の心因の存在や情緒的素因を把握して 治療を進めるうえで，問診が重要である．問診では患 者の心因的あるいは身体的背景を病歷, 生活歷の聴取 から十分に把握することが肝要である。その際, 患者 の声の使い方の詳細を尋ねるとともに, 発声に際して の心理的な状態，たとえば職場での心理的ストレスの 有無などにも注意して話を聞くことによって，実際の 声の使用状況などが把握できると廣瀬 ${ }^{1}$ は述べてい る.

VHI は患者の音声障害に対する身体・精神・心理学 的評価法として近年注目されている.Franic ら ${ }^{10}$ は, 音声障害に対する QOL 評価の指標の一つとして VHI について検討を行い，VHI が他の評価法に比べ て信頼度が高かったと報告した。われわれもVHIの 日本語版を作成し，音声障害症例の自覚的評価を検討 し，その有用性を報告した ${ }^{4)}$. 今回われわれが検討した VHI スコアの結果から, 機能性発声障害患者に対して 聞くべき問診のポイントとして，1自分の声に対して 努力をしているか? (2)発声時に緊張感があるか? という 2 つが挙げられる.努力感を感じるというのは, 発声に関してのコンプレックスを強くもっていること が考えられる。したがって，コンプレックスを抱くこ とにより発声時の緊張感が生じるのではないかと考え られる。特に, 過緊張性と思われる症例では, (1)声に より社会生活に制限がかかる，(2)声に対する不安を感 じる，という項目のスコアが高值を示していた。この ことから過緊張性の症例では発声に対するコンプレッ クスが生じた結果, 社会生活への不安が生じストレス が負荷されるという悪循環が生じていると考えられ
る. 以上のような VHI の検討結果から, 機能性発声障 害が疑われる症例においては, 発声時の努力感や緊張 感, 社会生活における支障度や不安感などについての 問診が重要と考えられた。

\section{ま と め}

$1 ）$ 機能性発声障害症例に対する問診においては症 状を詳細に聴取するとともに, 発症機転・心因的背景 を聞き出すことが重要である。

2) Voice Handicap Index (VHI) の日本語版を用 いて, 機能性発声障害症例の自覚的評価を行うことで, 機能性発声障害における心理社会的な問題をより的確 にとらえることができた。

3) VHI スコアは 40 歳代, 過緊張性発声障害症例 において高值を示し, 側面別では感情的側面のスコア が他疾患より高い傾向にあった。

4) VHI の結果より, 機能性発声障害が疑われる症 例においては，発声時の努力感や発声障害による社会 生活上の不安感などに関する問診が重要と考えられ た。

\section{文献}

1）廣瀬 肇：音声障害の臨床, インテルナ出版, 東京, 1998.

2) Jacobson BH, Johnson A, Grywalski C, et al: The Voice Handicap Index (VHI): development and validation. Am J Speech-Lang Pathol, 6: 66-70, 1997.

3）香田千絵子, 濱川幸代, 森 一功, 他：機能性発声障害の 臨床的検討. 音声言語医学, 40:1-9, 1999 .

4）田口亜紀, 兵頭政光, 三瀬和代, 他：Voice Handicap Index 日本語版による音声障害の自覚度評価.音声言語医学, 47 : 372-378, 2006 .

5) Rosen CA, Murry T, Zinn A, et al: Voice Handicap Index change following treatment of voice disorders. J Voice, 14: 619-623, 2000.

6) 廣瀬 肇：音声言語医学領域の用語とその解説 (3).音声言 語医学, 32：149-153, 1991.

7）牛嶋達次郎：機能性発声障害一診断と治療の基本. 音声言 語医学, $28: 276-278,1987$.

8）廣瀬 肇：機能性発声障害. 耳鼻臨床，80：1334-1338, 1987.

9）城本 修, 城本貞子, 田中信三, 他：機能性発声障害に対 する音声治療の効果. 耳鼻臨床, 補 $62 ： 86-90,1993$.

10) Franic DM, Bramlett RE and Bothe AC: Psychometric evaluation of disease specific quality of life instruments in voice disorders. J Voice, 19: 300-315, 2005.

別刷請求先：=791-0295 愛媛県東温市志津川 愛媛大学医学部耳鼻咽喉科学教室 田口亜紀 